\title{
Decoupling Process from Form in Landscape Evolution Studies
}

\section{D.W. Hedding, Dept. of Geography, University of South Africa, Florida 1710,South Africa,heddidw@unisa.ac.za}

According to Cruden (2003), the term "landslide" was first recorded in 1838 by J.D. Dana. Varnes (1958) used "landslide" in the title of his well-known paper but subsequently abandoned the term in favor of "slope" in the updated iteration (see Varnes, 1978). Varnes (1978, p. 11) states that the reason for the change is that "improvements in technical communication require a deliberate and sustained effort to increase the precision associated with the meaning of words, and therefore the term slide will not be used to refer to movements that do not include sliding." Later, Cruden (1991, p. 28) suggested that a landslide is "the movement of a mass of rock, earth or debris down a slope" and is intended for informal, non-technical use. Several other definitions have been suggested; however, Shanmugam (2015) notes that the term "landslide" lacks conceptual clarity. Nevertheless, the term "landslide" remains entrenched in the literature and, with each scientific discipline using its own nomenclatural scheme, it means different things to different groups (Shanmugam, 2015).

In the study of landscape evolution, the transfer of considerable volumes of material downslope under the influence of gravity plays a significant role in shaping landscapes (Cendrero and Dramis, 1996). As such, various papers assess the role and significance of slope processes and resultant mass movements in landscape evolution, typically within the context of quantifying erosion rates (Roda-Boluda et al., 2019) and/ or the roles of tectonic and climatic factors in weathering (Emberson et al., 2016). Often the terms "landsliding" or "bedrock landsliding" are used to describe the process by which material moves downslope (Egholm et al., 2013; Roering et al., 2001, 2005). However, their usage demonstrates a poor appreciation of the difference between process and form in geomorphology since these terms are intrinsically linked to landslides that are a discrete geomorphological landform and not to the range of process(es) that are responsible for the movement of material downslope in landscape evolution. In addition, form-convergence (equifinality) suggests that morphologically similar landforms can be generated by different processes, on their own or in combination, which complicates the correct identification of the process-origin of landforms (Hedding, 2016; Hedding et al., 2018). Still, the term "landsliding" is often described as the process responsible for the movement of material downslope and has received a level of credence (see Roering et al., 2001) through repetition and subsequent acceptance in the literature, rather than recognition of the actual process-form relationships. Notwithstanding the poor phrasing, the term "landsliding" is sometimes used as a synonym for "mass wasting." However, the movement of material downslope in landscape evolution can be generated through a suite of mass wasting (movement) processes resulting in landforms (e.g., catastrophic mudflows and rockfalls) and not solely from movement of material along a plane of weakness resulting in various types of landslides. In particular, the relative contribution of material through rockfall activity may be critical, specifically in seismically active regions where topographic amplification of seismic waves along ridgelines, which are not supported laterally, can produce significant volumes of debris. Thus, conflation of process and form in terminology used across the disciplines encompassed by the geosciences (e.g., geology, geochemistry, geomorphology, and sedimentology) may lead to a limited understanding of the processes responsible for landscape evolution and denudation, particularly where English may be the second language of the researcher and a literal or direct interpretation is utilized. To resolve the potential confusion, the term "landsliding" should be abandoned and replaced with the term "mass wasting," an established term in geomorphology, to decouple process(es) from form(s) in research on landscape evolution and in other geosciences. Mass wasting is an encompassing term that refers specifically to the processes responsible for the movement of material downslope. In addition, "deep-seated mass wasting" should be used to replace "bedrock-landsliding" in the lexicon of landscape evolution. To avoid further confusion, it is pertinent to highlight that "mass movements" is a term used to describe the resultant landforms generated through the processes of mass wasting.

\section{REFERENCES CITED}

Cendrero, A., and Dramis, F., 1996, The contribution of landslides to landscape evolution in Europe: Geomorphology, v. 15, p. 191-211, https://doi.org/10.1016/0169 $-555 X(95) 00070-\mathrm{L}$

Cruden, D.M., 1991, A simple definition of a landslide: Bulletin of the International Association of Engineering Geology, v. 43, p. 27-29, https://doi.org/10.1007/ BF02590167.

Cruden, D.M., 2003, The first classification of landslides?: Environmental \& Engineering Geoscience, v. 9, p. 197-200, https://doi.org/10.2113/9.3.197.

Egholm, D.L., Knudsen, M.F., and Sandiford, M., 2013, Lifespan of mountain ranges scaled by feedbacks between landsliding and erosion by rivers: Nature, v. 498, p. 475, https://doi.org/10.1038/nature12218.

Emberson, R., Hovius, N., Galy, A., and Marc, O., 2016, Chemical weathering in active mountain belts controlled by stochastic bedrock landsliding: Nature Geoscience, v. 9, p. 42-45, https://doi.org/10.1038/ngeo2600.

Hedding, D.W., 2016, Pronival ramparts: Origin and development of terminology: Erdkunde, v. 70, p. 141-151, https://doi.org/10.3112/erdkunde.2016.02.03.

Hedding, D.W., Brook, M.S., and Winkler, S., 2018, Old landscape, new eyes: Revisiting geomorphological research in the Southern Alps of New Zealand: New Zealand Geographer, v. 74, p. 109-112, https://doi.org/10.1111/nzg.12189.

Roda-Boluda, D.C., D’Arcy, M., Whittaker, A.C., Gheorghiu, D.M., and Rodés, A., $2019,{ }^{10} \mathrm{Be}$ erosion rates controlled by transient response to normal faulting through incision and landsliding: Earth and Planetary Science Letters, v. 507, p. 140-153, https://doi.org/10.1016/j.epsl.2018.11.032.

Roering, J.J., Kirchner, J.W., Sklar, L.S., and Dietrich, W.E., 2001, Hillslope evolution by nonlinear creep and landsliding: An experimental study: Geology, v. 29, p. 143-146, https://doi.org/10.1130/0091-7613(2001)029<0143:HEBNCA>2.0.CO;2.

Roering, J.J., Kirchner, J.W., and Dietrich, W.E., 2005, Characterizing structural and lithologic controls on deep-seated landsliding: Implications for topographic relief and landscape evolution in the Oregon Coast Range, USA: Geological Society of America Bulletin, v. 117, no. 5-6, p. 654-668, https://doi.org/10.1130/B25567.1.

Shanmugam, G., 2015, The landslide problem: Journal of Palaeogeography, v. 4, no. 2, p. 109-166, https://doi.org/10.3724/SP.J.1261.2015.00071.

Varnes, D.J., 1958, Landslide types and processes, in Eckel, E.B., ed., Landslide and Engineering Practice: Highway Research Board Special Report, v. 29, p. 20-47.

Varnes, D.J., 1978, Slope movement types and processes, in Schuster, R.L., and Krizek, R.J., eds., Landslides: Analysis and Control: Washington, D.C., National Academies of Science, Special Report 176, p. 11-33.

ManusCript ReCEIVEd 19 SEPT. 2019

REVISED MANUSCRIPT RECEIVED 11 Nov. 2019

MANUSCRIPT ACCEPTED 16 Nov. 2019 